\title{
Effects of different standardized ileal digestible lysine: net energy proportion in growing and finishing pigs
}

\author{
Ji Hwan Lee ${ }^{1 \#, ~ S u n g ~ D a e ~ L e e ~}{ }^{2 \#}$, Won Yun ${ }^{1}$, Han Jin Oh ${ }^{1}$, Ji Seon An", \\ In $\mathrm{Ho} \mathrm{Kim}^{3 *}$ and Jin $\mathrm{Ho} \mathrm{Cho}^{1 *}$ \\ ${ }^{1}$ Division of Food and Animal Science, Chungbuk National University, Cheongju 28644, Korea \\ ${ }^{2}$ Animal Nutritional Physiology Team, National Institute of Animal Science, Rural Development \\ Administration, Wanju 55365, Korea \\ ${ }^{3}$ Department of Animal Resource and Science, Dankook University, Cheonan 31116, Korea
}

Received: Jan 14, 2020

Revised: Jan 31, 2020

Accepted: Feb 4, 2020

\# These authors contributed equally to this work.

${ }^{*}$ Corresponding author In Ho Kim

Department of Animal Resource and

Science, Dankook University,

Cheonan 31116, Korea.

Tel: +82-41-550-3652

E-mail: inhokim@dankook.ac.kr

\section{Jin Ho Cho}

Division of Food and Animal Science, Chungbuk National University,

Cheongju 28644, Korea.

Tel: +82-43-261-2544

E-mail: jinhcho@chungbuk.ac.kr

Copyright (C) 2020 Korean Society of Animal Sciences and Technology.

This is an Open Access article distributed under the terms of the Creative Commons Attribution Non-Commercial License (http:// creativecommons.org/licenses/by$\mathrm{nc} / 4.0 /$ ) which permits unrestricted non-commercial use, distribution, and reproduction in any medium, provided the original work is properly cited.

ORCID

Ji Hwan Lee

https://orcid.org/0000-0001-8161-4853

Sung Dae Lee

https://orcid.org/0000-0002-9167-4099

Won Yun

https://orcid.org/0000-0002-1835-2640

\begin{abstract}
This experiment was performed to evaluate the optimal proportion of dietary standardized ileal digestible lysine (SID Lys) to net energy (NE) proportion in growing to finishing pigs. A total of seventy-two pigs were used at phase 1 (initial body weight $37.23 \pm 0.23$ kilogram, for $42 \mathrm{~d}$ ) and at phase 2 (initial body weight $54.16 \pm 0.20$ kilogram, for $77 \mathrm{~d}$ ). They were arbitrarily assigned to three treatments groups consisting of four duplicates per treatment (six pigs in duplicates, respectively). Diet treatments were as follows: $\mathrm{CON}=$ basal diets (phase 1, crude protein (CP): 19.1\%; SID Lys: 0.94\%; SID Lys: NE proportion: $0.91 \mathrm{~g} / \mathrm{MJ} /$ phase 2, CP: 17.0\%; SID Lys: 0.84\%; SID Lys: NE proportion: 0.79 g/MJ), TRT1 (phase 1, CP: 18.0\%; SID Lys: 0.92\%; SID Lys: NE proportion: 0.89 g/MJ / phase 2, CP: $15.8 \%$; SID Lys: $0.8 \%$; SID Lys: NE proportion: 0.75 g/MJ), TRT2 (phase 1, CP: 17.3\%; SID Lys: 0.82\%; SID Lys: NE proportion: 0.79 g/MJ / phase 2, CP: 14.8\%; SID Lys: 0.7\%; SID Lys: NE proportion: 0.65 g/MJ). In phase 1 and 2, growth performance did not meaningfully be affected when SID Lys: $\mathrm{NE}$ proportion decreased with reducing $\mathrm{CP}$ content. In phase 2, the nitrogen digestibility of CON group in 11 week was higher $(p<0.05)$ than other treatments. Also, marbling and firmness scores of TRT2 group diets increased $(p<0.05)$ compared with those of CON group, but dissimilarities of other meat qualities did not be detected among treatments. In conclusion, introduction of NE system can reduce negative problems introduced when dietary $\mathrm{CP}$ decreased. Also, 0.79 and $0.65 \mathrm{~g} / \mathrm{MJ}$ of SID Lys: NE proportion is the optimal Lys: NE proportion to achieve improved pork quality without impairing the growth performance in growing-finishing pigs, respectively.
\end{abstract}

Keywords: Digestibility, Growth performance, Meat quality, SID lysine: net energy

\section{INTRODUCTION}

Participants in the pig industry had added excess nutrition in diet over their requirements because 
Han Jin Oh

https://orcid.org/0000-0002-3396-483X

Ji Seon An

https://orcid.org/0000-0002-9205-8095

In Ho Kim

https://orcid.org/0000-0001-6652-2504

Jin Ho Cho

https://orcid.org/0000-0001-7151-0778

Competing interests

The authors declare no conflict of interest.

Funding sources

This work was supported by the National Research Foundation of Korea (NRF) grant funded by the Korea government (MSIT) (No. NRF-2019R1F1A1060192).

Acknowledgements

Not applicable.

Availability of data and material Upon reasonable request, the datasets of this study can be available from the corresponding author.

Authors' contributions

Conceptualization: Lee JH, Lee SD, Kim IH, Cho JH.

Data curation: Lee JH, Lee SD, Yun W, Oh HJ,

An JS.

Formal analysis: Lee JH, Lee SD

Investigation: Yun W, Oh HJ, An JS.

Writing - original draft: Lee JH, Lee SD, Kim IH, Cho JH.

Writing - review \& editing: $\mathrm{Kim} \mathrm{IH}, \mathrm{Cho} \mathrm{JH}$.

Ethics approval and consent to participate All manuals were used in the experiment were accepted from animal management and use commission of Chungbuk National University. they want to achieve the improving growth. Notably, the nitrogen of these excessive nutrients can result in environmental pollution by excretion into feces and urine [1]. For solving these problems, researchers have studied on effects of low protein in the diet, which caused the positive impact and negative impact on pigs. Some researches had shown that low crude protein in diet did not influence growth performance, but meaningfully reduced $\mathrm{N}$ emission by $10 \%$ and odor gas such as ammonia and volatility fatty acids [2,3]. However, pigs fed the low protein diets had more body fat than pigs fed the high protein diets in carcass. The introduction of net energy (NE) system has been used as a method to fulfil satisfied growth, carcass traits and meat quality by several researchers in the last few years [4,5]. Some research reported that the reported optimum proportion of standardized digestible lysine (Lys): NE proportion for growing-finishing pigs (27 to $100 \mathrm{~kg}$ ) is from 0.85 to $0.70 \mathrm{~g} / \mathrm{MJ}$, but other research showed that standardized digestible Lys: NE proportion for growing-finishing pigs (27 to $100 \mathrm{~kg}$ ) is from 1.11 to $0.78 \mathrm{~g} / \mathrm{MJ}$ [6,7]. Difference discovered between these studies can be attributed to the various reasons such as type of feedstuffs, the dietary crude protein $(\mathrm{CP})$ and NE content, the age and genotype of the pigs used [8]. Therefore, we carried out the investigation on the effects of different Lys: NE proportion with reducing crude protein in growing-finishing pigs.

\section{MATERIALS AND METHODS}

All manuals used in the experiment were accepted from animal management and use commission of Chungbuk National University.

\section{Animals and facilities}

In phase 1, seventy-two crossbred [(Landrace $\times$ Yorkshire $) \times$ Duroc) $]$ growing pigs weighted 37.23 \pm 0.23 kilogram (85-d age) were applied in an experimental period of 42 days at Chungbuk National University research farm. Pigs were arbitrarily assigned to 3 treatment groups consisting of four duplicates per treatment with six pigs (three barrows and three gilts) in duplicates, respectively. In phase 2, seventy-two crossbred [(Landrace $\times$ Yorkshire $) \times$ Duroc)] finishing pigs weighted 54.16 \pm 0.20 kilogram (110-d age) were divided again randomly to 3 dietary treatments consisting of four duplicates per treatment with six pigs (three barrows and three gilts) in duplicates, respectively and the experiment lasted 77 days. All pigs were raised in the room where it is possible to control temperature and humidity. Respective pen was fitted out feeder and a teat drinker which made from stainless steel on one side, and pigs were offered feed and water freely. Body weights (BW) of pigs were measured at the initial and final experiment period in phase 1 and initial, middle (d 42) and final ( $\mathrm{d}$ 77) experiment period in phase 2. Feed exhaustion were noted according to a pen for this experiment to settle the average daily gain (ADG), average daily feed intake (ADFI), and gain: feed ratio (G:F).

\section{Dietary treatments}

In phase 1 , the diets (Table 1 ) were designed to hold 191,180 , and $173 \mathrm{~g} / \mathrm{kg} \mathrm{CP}$, and standardized ileal digestible lysine (SID Lys): NE proportions of $0.91,0.89$, and $0.79 \mathrm{~g} / \mathrm{MJ} \mathrm{NE}$. In phase 2, the diets (Table 1) were mixed to have 170,158, and $148 \mathrm{~g} / \mathrm{kg} \mathrm{CP}$, and $0.79,0.75$, and $0.65 \mathrm{~g} / \mathrm{MJ}$ NE. Dietary CP and lysine content in CON diets were set in NRC [1]. Treatments reduced the dietary CP content by $1 \%$ and 2\%, respectively. All diets in phase 1 and phase 2 were designed to hold $10.38 \mathrm{MJ} / \mathrm{kg}$ of NE based on NRC [1]. NE figures used for ingredient (corn, soybean meal, wheat, etc) were $11.43,8.75,6.99$, and $30.40 \mathrm{MJ} / \mathrm{kg}$, respectively. Dietary $\mathrm{NE}$ levels were calculated in accordance with method of [9] and were established on chemical evaluation of diet raw material 
Table 1. Compositions of growing-finishing pig diets for phase 1 and phase 2 (as-fed basis)

\begin{tabular}{|c|c|c|c|c|c|c|}
\hline \multirow{2}{*}{ Item } & \multicolumn{3}{|c|}{ Phase $1^{1)}$} & \multicolumn{3}{|c|}{ Phase $2^{2)}$} \\
\hline & CON & TRT1 & TRT2 & CON & TRT1 & TRT2 \\
\hline \multicolumn{7}{|l|}{ Ingredients $(\mathrm{g} / \mathrm{kg})$} \\
\hline Corn & 440.1 & 412.6 & 461.3 & 454.9 & 479.4 & 508.0 \\
\hline Wheat & 111.5 & 150.0 & 150.0 & 150.0 & 150.0 & 150.0 \\
\hline Soybean meal (48\%) & 231.0 & 226.0 & 173.0 & 173.4 & 166.5 & 139.0 \\
\hline Milk product & 30.0 & 30.0 & 30.0 & 30.0 & 30.0 & 30.0 \\
\hline DDGS & 80.0 & 80.0 & 80.0 & 80.0 & 80.0 & 80.0 \\
\hline Rice bran & 10.0 & 20.0 & 20.0 & 20.0 & 20.0 & 20.0 \\
\hline Tallow & 32.3 & 23.3 & 19.3 & 28.5 & 15.5 & 12.8 \\
\hline Molasses & 30.0 & 30.0 & 30.0 & 30.0 & 30.0 & 30.0 \\
\hline Dicalcium phosphate & 0.25 & 0.25 & 0.30 & 0.25 & 0.25 & 0.25 \\
\hline Limestone & 16.8 & 14.0 & 14.0 & 17.3 & 13.3 & 13.5 \\
\hline Salt & 3.0 & 3.0 & 3.0 & 3.0 & 3.0 & 3.0 \\
\hline Choline chloride & 0.8 & 0.8 & 0.8 & 0.8 & 0.8 & 0.8 \\
\hline L-Lysine (98.5\%) & 8.3 & 3.9 & 10.0 & 5.7 & 5.2 & 6.4 \\
\hline DL-Methionine (99\%) & 0.5 & 0.6 & 1.4 & 0.6 & 0.4 & 0.5 \\
\hline L-Threonine (99\%) & 0.2 & 0.3 & 1.2 & 0.3 & 0.4 & 0.5 \\
\hline Vitamin premix ${ }^{3)}$ & 2.0 & 2.0 & 2.0 & 2.0 & 2.0 & 2.0 \\
\hline Trace mineral premix ${ }^{4)}$ & 1.0 & 1.0 & 1.0 & 1.0 & 1.0 & 1.0 \\
\hline \multicolumn{7}{|l|}{ Calculated compisition ${ }^{5)}$} \\
\hline $\mathrm{NE}(\mathrm{MJ} / \mathrm{kg})$ & 10.38 & 10.38 & 10.38 & 10.38 & 10.38 & 10.38 \\
\hline Crude protein (\%) & 19.1 & 18.0 & 17.3 & 17.0 & 15.8 & 14.8 \\
\hline Crude fat (\%) & 6.49 & 5.75 & 5.46 & 6.36 & 5.15 & 4.94 \\
\hline SID Lys (\%) & 0.94 & 0.92 & 0.82 & 0.84 & 0.80 & 0.70 \\
\hline $\mathrm{Ca}(\%)$ & 0.8 & 0.7 & 0.7 & 0.81 & 0.66 & 0.66 \\
\hline Total P (\%) & 0.63 & 0.66 & 0.65 & 0.63 & 0.63 & 0.62 \\
\hline SID Lys:NE ratio (g/MJ) & 0.91 & 0.89 & 0.79 & 0.79 & 0.75 & 0.65 \\
\hline
\end{tabular}

${ }^{11)} \mathrm{CON}$ (CP: 19.1\%, SID Lys: 0.94\%, NE: 10.38 MJ/kg, SID Lys: NE: 0.91 g/MJ); TRT1 (CP: 18.0\%, SID Lys: 0.92\%, NE: 10.38 MJ/kg, SID Lys: NE: 0.89 g/MJ); TRT2 (CP: 17.3\%, SID Lys: 0.82\%, NE: 10.38 MJ/kg, SID Lys: NE: 0.79 g/MJ).

${ }^{2} \mathrm{C} C \mathrm{~N}$ (CP: $17.0 \%$, SID Lys: 0.84\%, NE: $10.38 \mathrm{MJ} / \mathrm{kg}$, SID Lys: NE: 0.79 g/MJ); TRT1 (CP: 15.8\%, SID Lys: 0.80\%, NE: 10.38 MJ/kg, SID Lys: NE: 0.75 g/MJ); TRT2 (CP: 14.8\%, SID Lys: 0.70\%, NE: 10.38 MJ/kg, SID Lys: NE: 0.65 g/MJ).

${ }^{3}$ Provided per kg of complete diet: vitamin A, 4,000 IU; vitamin $\mathrm{D}_{3}, 800 \mathrm{IU}$; vitamin E, $171 \mathrm{IU}$; vitamin $\mathrm{K}, 2 \mathrm{mg}$; riboflavin, $4 \mathrm{mg}$; niacin, $20 \mathrm{mg}$; thiamine, $4 \mathrm{mg}$; d-pantothenic, $11 \mathrm{mg}$; choline, $166 \mathrm{mg}$; biotin, $0.08 \mathrm{mg}$; and vitamin $\mathrm{B}_{12}, 16 \mu \mathrm{g}$.

${ }^{4}$ Provided per kg of complete diet: $\mathrm{Cu}$ (as $\mathrm{CuSO}_{4} \cdot 5 \mathrm{H}_{2} \mathrm{O}$ ), $15 \mathrm{mg}$; Fe (as $\mathrm{FeSO}_{4} \cdot 7 \mathrm{H}_{2} \mathrm{O}$ ), $80 \mathrm{mg} ; \mathrm{Zn}\left(\right.$ as $\mathrm{ZnSO}_{4}$ ), $56 \mathrm{mg} ; \mathrm{Mn}$ $\left(\mathrm{MnO}_{2}\right), 74 \mathrm{mg} ; \mathrm{I}$ (as KI), $0.3 \mathrm{mg}$; Co (as $\left.\mathrm{CoSO}_{4} \cdot 5 \mathrm{H}_{2} \mathrm{O}\right), 0.5 \mathrm{mg}$; and Se $\left(\right.$ as $\left.\mathrm{Na}_{2} \mathrm{SeO}_{3} \cdot 5 \mathrm{H}_{2} \mathrm{O}\right), 0.4 \mathrm{mg}$.

${ }^{5)}$ Calculated value.

DDGS, dried distillers grains with solubles; $N E$, net energy; SID Lys, standardized ileal digestible lysine; $C P$, crude protein.

for $\mathrm{CP}$, ether extract (EE) and crude fiber (CF) [10]. Besides the starch content was estimated by manual of [11]. The true NE figure of crystal structure of lysine, methionine, and threonine used on this study was $14.09,17.31$, and $12.30 \mathrm{MJ} / \mathrm{kg}$ of DM in each by applying INRA and AFZ figures [12].

The tangible equation applied to the computation of NE was: $\mathrm{NE}=(0.00294 \times \mathrm{MJ} / \mathrm{kg}$ Digestible energy $)+(1.58 \times \mathrm{g} / \mathrm{kg}$ ether extract $)+(0.47 \times \mathrm{g} / \mathrm{kg}$ Starch $)-(0.97 \times \mathrm{g} / \mathrm{kg}$ Crude protein $)-(0.98$ $\times \mathrm{g} / \mathrm{kg}$ Crude fiber).

Other constituents of feed were mixed to satisfy or surpass the nutrient demand [1] for 30-50 $\mathrm{kg}$ of BW growing pigs and 50 to $110 \mathrm{~kg}$ of finishing pigs and fed a coarse form. 


\section{Sampling and measurements}

The apparent total tract digestibility (ATTD) of gross energy (GE), dry matter (DM) and nitrogen (N) were settled into usage of chromic oxide $(2 \mathrm{~g} / \mathrm{kg})$ as an inactive maker [13]. Pigs were supplied feed containing chromic oxide on 35 and 70 days in phase 1 and 2 respectively. Fresh feces were gathered into respective pen (phase 1 for 41 day; phase 2 from 41 to 76 day), and these samples were saved in a refrigerator at $-20^{\circ} \mathrm{C}$ until analysis. All diets and feces samples were evaluated for $\mathrm{DM}$ and $\mathrm{N}$ following the procedures outlined [10]. $\mathrm{N}$ and GE were settled with a Kjeltec 2300 nitrogen analyzer (Foss Tecator AB, Hoeganaes, Sweden) and Parr 6100 oxygen bomb calorimeter (Parr Instrument, Moline, IL). Chromium was analyzed via UV absorption spectrophotometry (Shimadzu UV-1201, Shimadzu, Kyoto, Japan) following the manuals described by [14].

The ATTD of DM and N were determined to use the following second-hand equations:

Computation equation of apparent total tract digestibility $=\{1-[(\mathrm{NCf} \times \mathrm{CCd}) /(\mathrm{NCd} \times \mathrm{CCf})]\} \times 100$,

$$
\begin{aligned}
& \mathrm{NCf}=\text { nutrient content } \text { of feces }(\% \mathrm{DM}), \\
& \mathrm{NCd}=\text { nutrient content of } \operatorname{diet}(\% \mathrm{DM}), \\
& \mathrm{CCf}=\text { chromium content of feces }(\% \mathrm{DM}), \\
& \mathrm{CCd}=\text { chromium content of diets }(\% \mathrm{DM}) .
\end{aligned}
$$

At the final study period, all of pigs were killed in a regional slaughterhouse. Hot carcass weight was immediately settled after slaughter, and fat back, muscular percentage, TBARS, meat color and muscle meat proportion were measured into usage of a real-time ultrasound instrument (Piglot 105, SFK Technology, Herlev, Denmark). After refrigerating at $2^{\circ} \mathrm{C}$ for $24 \mathrm{~h}$, longissimus muscle sample was removed to $2.54 \mathrm{~cm}$ between 10th and 11th rib (pigs' right side). Sensory evaluation including marbling, intramuscular fat, color and firmness scores) were determined by described manuals of [15]. Drip loss was evaluated by the proportion of the initial weight applying $2 \mathrm{~g}$ of meat sample in accordance with the manual of [16]. Replicate $\mathrm{pH}$ figure of respective sample was determined into usage of a glass-electrode $\mathrm{pH}$ meter (WTW pH 340-A, Wtw Measurement Systems, Ft. Myers, FL, USA). Water holding capacity (WHC) was determined via the instruction of [17]. Longissimus muscle area (LMA) was determined through finding the longissimus muscle exterior at the 10th rib, which also employed the digitizing area-line sensor. The final rib of backfat thickness which determined at the median of separated corpse were revised by usage of regression assay for the average final BW before being gathered using the equation suggested by [15].

\section{Statistical analysis}

In this experiments, all data were analyzed by ANOVA applying the General Linear Models (GLM) procedures of SAS (SAS Institute, 2008), with the pen as the experimental unit. Dissimilarities between dietary treatment were settled using Duncan's multiple range tests. All consequences were presented in the table as means, standard error (SE) and $p$-values of $<0.05$. A $p$-values were meant statistically significant.

\section{RESULTS}

\section{Growth performance and nutrient digestibility}

In phase 1, growth performance including ADG, ADFI, and G:F ratio did not show meaningful dissimilarities between the treatments (Table 2). In common with growth performance, digestibility of DM, N, and GE did not show dissimilarities among the treatments on day 42 . In phase 2, each 
period ( 0 to 42 day; 42 to 77 day) and the whole period ( 0 to 77 day), there were nothing to change on BW, ADG, ADFI and G: F ratio among treatments (Table 3). At 43 and 77 day, no dissimilarities in the ATTD of DM and energy were checked between treatments (Table 4). On the other hand, the CON group had a greater $\mathrm{N}$ digestibility $(p<0.05)$ than that of TRT2 group.

\section{Meat quality}

There were no dissimilarities among dietary treatments on hot carcass traits (HCW), $\mathrm{pH}$ value, drip loss percentage, WHC, TBARS concentration, LMA, and backfat thickness (Table 5). In Minolta color parameter, lightness ( $\left.\mathrm{L}^{*}\right)$ of TRT2 group was analogous to that of CON and TRT1 group. Redness $\left(a^{*}\right)$ was meaningfully decreased $(p<0.05)$ when SID Lys: NE proportion decreased. The color of TRT2 group was meaningfully increased $(p<0.05)$ compared with that of CON group but was analogous to that of TRT1 group. The marbling and firmness scores improved $(p<0.05)$ when SID Lys: NE proportion decreased.

\section{DISCUSSION}

\section{Growth performance and nutrient digestibility}

Generally, diets with low crude protein caused reducing growth rate and feed efficiency compared with diets with high protein [18]. Also, $2 \%$ reduction of dietary CP decreased pig's growth performance [19]. However, diets of reducing Lys: NE proportion with low dietary CP did not cause the change of growth performance in growing and finishing phases in the current study (Tables 2 and 3). Results obtained in the current study were in accordance with many former studies, which reported no change in growth performance of pig incepted low protein diet [6,20]. These contradictory results could be explained by the use of different energy system in this experiment. Digestible energy (DE) or metabolic energy (ME) system had been used in almost every previous experiment. However, net energy (NE) used in this study represents more accurate energy content than DE and ME, and is considered independent of the feed intake. Actually, Campbell \& Taverner [21] employed iso-energetic feeds with various protein contents and observed no dissimilarity in ADFI. Also, other researcher reported that $\mathrm{NE}$ content in diets did not influence the $\mathrm{ADFI}$ in finishing pigs [22]

Table 2. Effect of reducing SID Lys: NE ratios on growth performance and nutrient digestibility in growing pigs (phase 1)

\begin{tabular}{lcccc}
\hline \multicolumn{1}{c}{ Items } & CON & TRT1 & TRT2 & SE \\
\hline Growth performance & & & & \\
Initial BW $(\mathrm{kg})$ & $37.42^{1)}$ & 37.01 & 37.25 & 0.61 \\
Final BW $(\mathrm{kg})$ & 67.46 & 66.24 & 66.37 & 0.67 \\
ADG $(\mathrm{g})$ & 715 & 696 & 693 & 16 \\
ADFI (g) & 1,512 & 1,481 & 1,519 & 27 \\
G:F ratio & 0.473 & 0.470 & 0.456 & 0.012 \\
Nutrient digestibility (\%) & & & & \\
Dry matter & 74.94 & 74.55 & 75.78 & 0.43 \\
Nitrogen & 67.58 & 69.09 & 70.06 & 0.82 \\
Gross energy & 73.28 & 72.85 & 72.79 & 0.43 \\
\hline
\end{tabular}

${ }^{1)}$ Each mean represents 4 pens with 6 pigs each per treatment. CON (CP: $19.1 \%$, SID Lys: $0.94 \%$, NE: 10.38 MJ/kg, SID Lys: NE: 0.91 g/MJ); TRT1 (CP: 18.0\%, SID Lys: 0.92\%, NE: 10.38 MJ/kg, SID Lys: NE: 0.89 g/MJ); TRT2 (CP: 17.3\%, SID Lys: $0.82 \%, \mathrm{NE}: 10.38 \mathrm{MJ} / \mathrm{kg}$, SID Lys: NE: $0.79 \mathrm{~g} / \mathrm{MJ})$.

$\mathrm{SE}$, standard error; BW, body weights; $A D G$, average daily gain; $A D F I$, average daily feed intake; G:F, gain to feed; $C P$, crude protein; SID Lys, standardized ileal digestible lysine; NE, net energy. 
Table 3. Effect of reducing SID Lys: NE ratios on growth performance in finishing pigs (phase 2)

\begin{tabular}{ccccc}
\hline Items & CON & TRT1 & TRT2 & SE \\
\hline Initial BW $(\mathrm{kg})$ & $54.31^{1)}$ & 54.19 & 53.99 & 1.42 \\
$42 \mathrm{~d} \mathrm{BW}(\mathrm{kg})$ & 88.12 & 87.58 & 86.96 & 1.28 \\
Final BW $(\mathrm{kg})$ & 119.06 & 118.35 & 117.80 & 1.13 \\
0-42 day & & & & \\
ADG (g) & 805 & 795 & 785 & 33 \\
ADFI (g) & 2,120 & 2,202 & 2,131 & 71 \\
G:F ratio & 0.380 & 0.361 & 0.368 & 0.011 \\
42-77 day & & & & 37 \\
ADG (g) & 884 & 879 & 881 & 98 \\
ADFI (g) & 2,732 & 2,676 & 2,652 & 0.019 \\
G:F ratio & 0.324 & 0.328 & 0.332 & \\
0-77 day & & & & 26 \\
ADG (g) & 841 & 833 & 829 & 65 \\
ADFI (g) & 2,398 & 2,418 & 2,368 & 0.011 \\
G:F ratio & 0.351 & 0.345 & 0.350 & \\
\hline
\end{tabular}

${ }^{1)}$ Each mean represents 4 pens with 6 pigs each per treatment. CON (CP: $17.0 \%$, SID Lys: $0.84 \%$, NE: $10.38 \mathrm{MJ} / \mathrm{kg}$, SID Lys: NE: 0.79 g/MJ); TRT1 (CP: 15.8\%, SID Lys: 0.80\%, NE: 10.38 MJ/kg, SID Lys: NE: 0.75 g/MJ); TRT2 (CP: 14.8\%, SID Lys: $0.70 \%, \mathrm{NE}: 10.38 \mathrm{MJ} / \mathrm{kg}$, SID Lys: NE: $0.65 \mathrm{~g} / \mathrm{MJ}$ ).

$\mathrm{SE}$, standard error; BW, body weights; ADG, average daily gain; ADFI, average daily feed intake; G:F, gain to feed; $C P$, crude protein; SID Lys, standardized ileal digestible lysine; NE, net energy.

Table 4. Effect of reducing SID Lys: NE ratios on nutrient digestibility in finishing pigs (phase 2)

\begin{tabular}{lllll}
\hline \multicolumn{1}{c}{ Items (\%) } & CON & TRT1 & TRT2 & SE \\
\hline 42 day & & & & \\
Dry matter & $80.39^{1)}$ & 79.79 & 78.39 & 0.98 \\
Nitrogen & 77.37 & 77.45 & 77.23 & 0.94 \\
Gross energy & 78.44 & 77.34 & 77.13 & 1.22 \\
77 day & & & & \\
Dry matter & 79.51 & 79.40 & 77.01 & 0.95 \\
Nitrogen & $79.78^{\mathrm{a}}$ & $77.79^{\mathrm{ab}}$ & $76.22^{\mathrm{b}}$ & 1.03 \\
Gross energy & 76.68 & 76.24 & 74.87 & 1.15 \\
\hline
\end{tabular}

${ }^{11}$ Each mean represents 4 pens with 6 pigs each per treatment. CON (CP: $17.0 \%$, SID Lys: $0.84 \%$, NE: $10.38 \mathrm{MJ} / \mathrm{kg}$, SID Lys: NE: 0.79 g/MJ); TRT1 (CP: 15.8\%, SID Lys: 0.80\%, NE: 10.38 MJ/kg, SID Lys: NE: 0.75 g/MJ); TRT2 (CP: 14.8\%, SID Lys: $0.70 \%, \mathrm{NE}: 10.38 \mathrm{MJ} / \mathrm{kg}$, SID Lys: NE: $0.65 \mathrm{~g} / \mathrm{MJ})$.

${ }^{a, b}$ Within a row, mean with different superscript differ $(p<0.05)$.

$\mathrm{SE}$, standard error; CP, crude protein; SID Lys, standardized ileal digestible lysine; NE, net energy.

and $\mathrm{NE}$ content with low $\mathrm{CP}$ did not cause influence on whole daily feed intake in growing pigs [4]. For nutrient digestibility, $\mathrm{He}$ et al. [23] showed that 6\% reduction of dietary $\mathrm{CP}$ indicated the highest ileal digestibility of $\mathrm{CP}$ and amino acid (AA). This notion was also supported by a number of published studies [24,25]. In the current study, ATTD of N in TRT2 group were lower $(p<0.05)$ than those of CON group at the last of phase 2, and there was also a trend in reduction of ATTD of $\mathrm{N}$ in TRT1 group (Table 4). This finding was different form that in other previous studies, so it need that more research is required. However, a reduction of dietary $\mathrm{CP}$ did not necessarily cause influence on the pigs' growth in our study. Therefore, introduction of NE system with $2 \%$ dietary $\mathrm{CP}$ can alleviate the established negative effect from reducing dietary $\mathrm{CP}$ in the nutritional strategy. 
Table 5. Effect of reducing SID Lys: NE ratios on meat quality in finishing pigs (phase 2)

\begin{tabular}{|c|c|c|c|c|}
\hline Items & CON & TRT1 & TRT2 & SE \\
\hline $\mathrm{HCW}(\mathrm{kg})$ & $90.2^{1)}$ & 90.9 & 91.3 & 0.50 \\
\hline $\mathrm{pH}$ value & 5.71 & 5.75 & 5.72 & 0.01 \\
\hline \multicolumn{5}{|l|}{ Drip loss (\%) } \\
\hline 1 day & 6.74 & 6.62 & 6.70 & 0.54 \\
\hline 3 day & 7.89 & 6.62 & 7.88 & 0.68 \\
\hline 5 day & 10.08 & 9.48 & 10.05 & 0.77 \\
\hline WHC (\%) & 40.39 & 38.01 & 39.14 & 2.27 \\
\hline \multicolumn{5}{|l|}{ Minolta color } \\
\hline Lightness $\left(L^{*}\right)$ & $51.44^{\mathrm{b}}$ & $54.41^{\mathrm{a}}$ & $53.70^{\mathrm{ab}}$ & 0.82 \\
\hline Redness $\left(a^{*}\right)$ & $18.21^{\mathrm{a}}$ & $17.14^{\mathrm{b}}$ & $17.18^{b}$ & 0.26 \\
\hline Yellowness (b*) & 6.79 & 7.86 & 7.36 & 0.33 \\
\hline \multicolumn{5}{|l|}{ Sensory evaluation } \\
\hline Color & $2.68^{\mathrm{a}}$ & $2.34^{b}$ & $2.60^{\mathrm{a}}$ & 0.08 \\
\hline Marbling & $1.22^{c}$ & $1.94^{\mathrm{b}}$ & $2.20^{\mathrm{a}}$ & 0.06 \\
\hline Firmness & $1.98^{\mathrm{b}}$ & $2.40^{\mathrm{a}}$ & $2.58^{\mathrm{a}}$ & 0.08 \\
\hline \multicolumn{5}{|l|}{ TBARS (mg MA/kg) } \\
\hline 0 day & 0.019 & 0.018 & 0.020 & 0.001 \\
\hline 5 day & 0.071 & 0.070 & 0.071 & 0.001 \\
\hline 10 day & 0.186 & 0.184 & 0.184 & 0.004 \\
\hline $\operatorname{LMA}\left(\mathrm{cm}^{2}\right)$ & 41.64 & 37.36 & 38.74 & 3.28 \\
\hline Backfat thickness (mm) & 19.6 & 20.3 & 20.6 & 0.31 \\
\hline
\end{tabular}

${ }^{1)}$ Each mean represents 4 pens with 6 pigs each per treatment. CON (CP: 17.0\%, SID Lys: 0.84\%, NE: 10.38 MJ/kg, SID Lys: NE: 0.79 g/MJ); TRT1 (CP: 15.8\%, SID Lys: 0.80\%, NE: 10.38 MJ/kg, SID Lys: NE: 0.75 g/MJ); TRT2 (CP: $14.8 \%$, SID Lys: $0.70 \%, \mathrm{NE}: 10.38 \mathrm{MJ} / \mathrm{kg}$, SID Lys: NE: $0.65 \mathrm{~g} / \mathrm{MJ})$.

a,b Within a row, mean with different superscript differ $(p<0.05)$.

SE, standard error; HCW, hot carcass weight; WHC, water hold capacity; TBARS, thiobarbituric acid reactive substance; LMA, longissimus muscle area; CP, crude protein; SID Lys, standardized ileal digestible lysine; NE, net energy.

\section{Meat quality}

Meat quality is an important economic trait and decides the preference of meat from customers. The main valuable elements are color, $\mathrm{pH}$, fat composition and drip loss [26,27]. In the current study, reducing Lys: NE proportion with reducing dietary $\mathrm{CP}$ does not influence on the ultimate results of $\mathrm{HCW}$, muscle $\mathrm{pH}$ value, drip loss percentage or other measures of WHC (Table 5). Results obtained in the current study were in accordance with many former studies [28,29]. Spencer et al. [30] reported that pigs (initial BW $=77 \mathrm{~kg}$ ) fed diets reduced by $23 \mathrm{~g} / \mathrm{kg} \mathrm{CP}(113 \mathrm{~g} / \mathrm{kg}$ dietary $\mathrm{CP}$ concentration compared with $136 \mathrm{~g} / \mathrm{kg}$ of CON diet), showed increased backfat and a trend to have smaller LMA. Also, Lee et al. [31] also found that LMA was lower in low (12\%) dietary CP than in high (16\%) and medium (14\%) dietary CP. The fatness in carcass increased when pigs fed with low-CP diet. This is because energy expenditure reduced in the catabolism of excess dietary protein [2]. Low protein diets lead to better utilization of energy due to a reduction of urinary energy losses and heat production, and this surplus energy promotes the retention of energy (particularly fat deposition) [6]. Therefore, excess energy is changed to fat, thereby creating a fatter carcass. Besides, a reducing dietary protein level and the following enrichment in carbohydrates or the same fat level with limiting essential amino acid would enable to improve the efficiency of energy utilization, causing increasing fat deposition in carcass [32]. However, in this study, there were no meaningful dissimilarities on backfat thickness and LMA among treatments. The dissimilarities between our 
current study may be caused by introduction of NE system. Therefore, the adoption of NE system with $2 \%$ dietary $\mathrm{CP}$ diets can alleviate the problems that could arise when pigs were consumed diets with low protein. During the past few years, the leaner genotypes were selected, resulting in reduced intramuscular fat (IMF) due to preference of consumer [33]. As time passed, their preference improved on the increasing IMF [34]. In the current study, IMF or marbling and firmness scores of TRT1 and TRT2 groups improved $(p<0.05)$ compared with those of CON group (Table 5). This result in the current study were in accordance with the former studies, which reported the IMF percentage was improved when dietary protein level was decreased by $3 \mathrm{~g} / \mathrm{kg}$ [18]. IMF was related to hardness, and the intensities of pork decreased IMF increased in beef [35]. Likewise, restricting dietary CP during the growing pig decreased the firmness and tended to raise the IMF content [36]. Thus, this result in the current study indicated that increasing IMF of pork decrease pork's firmness scores. The $\mathrm{a}^{*}$ figures are colour coordinates indicating a difference from green to red color. An increasing $\mathrm{a}^{*}$ figures indicates that a sample had more red color and decreasing $\mathrm{a}^{*}$ figures represents that color tended to be green. The $b^{*}$ figures are also colour coordinates, indicating a difference in color from blue to yellow. An increasing $b^{*}$ value indicates that a sample had more blue color and decreasing $\mathrm{a}^{*}$ figures represents that color tended to be yellow [37]. The $\mathrm{L}^{*}$ indicates a sample with more brightness. In the current results, the $\mathrm{L}^{*}$ increased, but $\mathrm{a}^{*}$ decreased when Lys: NE proportion was reduced. Cameron et al. [38] reported that the $\mathrm{a}^{*}, \mathrm{~b}^{*}$ and chroma figures of meat obtained from pigs fed a diet holding $0.42 \mathrm{~g}$ of lysine/MJ of $\mathrm{ME}$ was higher than that from pigs fed diets either 0.80 or $1.17 \mathrm{~g}$ of lysine/MJ of ME. Moreover, some studies reported that meat color ( $\mathrm{L}^{*}, \mathrm{a}^{*}$, and $\left.\mathrm{b}^{*}\right)$ increased when dietary $\mathrm{CP}$ was decreased [36]. The dissimilarities between our current study and these findings may be generated by different strains of pigs and different analytical methods [39].

\section{CONCLUSION}

The application of NE system can alleviate adverse effect such as reduction of growth and fatness carcass when dietary $\mathrm{CP}$ decreased. Also, approximately 0.79 and $0.65 \mathrm{~g} / \mathrm{MJ}$ of SID Lys: NE proportion is supposed to be the optimum SID Lys: NE proportion to attain improved pork quality without impairing growth performance in growing and finishing pigs, respectively.

\section{REFERENCES}

1. NRC [National Research Council]. Nutrient requirement of swine. 11th ed. Washington, DC: National Academy Press; 2012.

2. Kerr BJ, Southern LL, Bidner TD, Friesen KG, Easter RA. Influence of dietary protein level, amino acid supplementation, and dietary energy levels on growing-finishing pig performance and carcass composition.J Anim Sci. 2003;81:3075-87.

3. Shriver JA, Carter SD, Sutton AL, Richert BT, Senne BW, Pettey LA. Effects of adding fiber sources to reduced-crude protein, amino acid-supplemented diets on nitrogen excretion, growth performance, and carcass traits of finishing pigs. J Anim Sci. 2003;81:492-502.

4. Yi X, Zhang S, Yang Q, Yin H, Qiao S. Influence of dietary net energy content on performance of growing pigs fed low crude protein diets supplemented with crystalline amino acids.J Swine Health Prod. 2010;18:294-300.

5. Tous N, Lizardo R, Vilà B, Gispert M, Font-i-Furnols M, Esteve-Garcia E. Effect of reducing dietary protein and lysine on growth performance, carcass characteristics, intramuscular fat, and fatty acid profile of finishing barrows. J Anim Sci. 2014;92:129-40.

6. Le Bellego L, van Milgen J, Noblet J. Effect of high temperature and low-protein diets on the 
performance of growing-finishing pigs. J Anim Sci. 2002;80:691-701.

7. PIC. PIC lysine requirement update: biology and economics. Nantwich, UK: PIC; 2016.

8. Nam DS, Aherne FX. The effects of lysine: energy ratio on the performance of weanling pigs.J Anim Sci. 1994;72:1247-56.

9. Noblet J, Fortune H, Shi XS, Dubois S. Prediction of net energy value of feeds for growing pigs. J Anim Sci. 1994;72:344-54.

10. AOAC [Association of Official Analytical Chemists] International. Official methods of analysis of AOAC International. 18th ed. Gaithersburg, MD: AOAC International; 2005.

11. Thivend P, Mercier C, Guilbot A. Determination of starch with glucoamylase. General Carbohydrate Method. 1972;6:100-5.

12. Sauvant D, Pérez JM, Tran G. Tables of composition and nutritional value of feed materials: pig, poultry, cattle, sheep, goats, rabbits, horses and fish. Wageningen: Wageningen Academic Publishers; 2004.

13. Fenton TW, Fenton M. An improved procedure for the determination of chromic oxide in feed and feces. Can J Anim Sci. 1979;59:631-4.

14. Williams $\mathrm{CH}$, David DJ, lismaa $\mathrm{O}$. The determination of chromic oxide in faeces samples by atomic absorption spectrophotometry.J Agric Sci. 1962;59:381-5.

15. NPPC [National Pork Producers Council]. Procedures to evaluate market hogs. 3rd ed. Des Moines, IA: NPPC; 1991.

16. Honikel KO. Reference methods for the assessment of physical characteristics of meat. Meat Sci. 1998;49:447-57.

17. Kauffman RG, Eikelenboom G, van der Wal PG, Engel B, Zaar M. A comparison of methods to estimate water-holding capacity in post-rigor porcine muscle. Meat Sci. 1986;18:307-22.

18. Teye GA, Sheard PR, Whittington FM, Nute GR, Stewart A, Wood JD. Influence of dietary oils and protein level on pork quality. 1. effects on muscle fatty acid composition, carcass, meat and eating quality. Meat Sci. 2006;73:157-65.

19. Lee JH, Kim HB, Yun W, Kwak WG, Lee CH, Oh HJ, et al. Effects of reducing dietary crude protein and metabolic energy in weaned piglets. S Afr J Anim Sci. 2017;47:574-81.

20. Powers W, Bastyr S, Angel R, Applegate T, Kerr B. Effects of reduced crude protein diets on gaseous emissions and swine performance. In: Proceedings of Workshop on Agricultural Air Quality: State of Science; 2006; Potomac, MD.

21. Campbell RG, Taverner MR. Genotype and sex effects on the relationship between energy intake and protein deposition in growing pigs.J Anim Sci. 1988;66:676-86.

22. Fracaroli C, Perondi D, dos Santos LS, da Silva WC, Veira AM, Hauschild L. Net energy levels of reduced crude protein, amino acid-supplemented diets for heavy pigs. Livest Sci. 2017;205:43-9.

23. He L, Wu L, Xu Z, Li T, Yao K, Cui Z, et al. Low-protein diets affect ileal amino acid digestibility and gene expression of digestive enzymes in growing and finishing pigs. Amino Acids. 2016;48:21-30.

24. Kulthe AA, Pawar VD, Kotecha PM, Chavan UD, Bansode VV. Development of high protein and low calorie cookies. J Food Sci Technol. 2014;51:153-7.

25. Sharma VC, Mahesh MS, Mohini M, Datt C, Nampoothiri VM. Nutrient utilisation and methane emissions in Sahiwal calves differing in residual feed intake. Arch Anim Nutr. 2014;68:345-57.

26. Rosenvold K, Andersen HJ. 2003. Factors of significance for pork quality: a review. Meat Sci. 2003;64:219-37.

27. Liu Y, Kong X, Jiang G, Tan B, Deng J, Yang X, et al. Effects of dietary protein/energy ratio 
on growth performance, carcass trait, meat quality, and plasma metabolites in pigs of different genotypes. J Anim Sci Biotechno. 2015;6:36.

28. Witte DP, Ellis M, McKeith FK, Wilson ER. Effect of dietary lysine level and environmental temperature during the finishing phase on the intramuscular fat content of pork. J Anim Sci. 2000;78:1272-6.

29. Zhang GJ, Yi XW, Chu LC, Lu N, Htoo J, Qiao SY. Effects of dietary net energy density and standardized ileal digestible lysine: net energy ratio on the performance and carcass characteristic of growing-finishing pigs fed low crude protein supplemented with crystalline amino acids diets. Agric Sci China. 2011;10:602-10.

30. Spencer JD, Gaines AM, Berg EP, Allee GL. Diet modifications to improve finishing pig growth performance and pork quality attributes during periods of heat stress. J Anim Sci. 2005;83:243-54.

31. Lee JH, Kim JD, Kim JH, Kim IH, Han K. Effect of different dietary CP levels on the growth, nutrient utilization and carcass characteristics of finishing barrows and gilts reared in phase feeding regimen. J Appl Anim Res. 2001;19:145-63.

32. Hongtrakul K, Goodband RD, Behnke KC, Nelssen JL, Tokach MD, Bergström JR, et al. The effects of extrusion processing of carbohydrate sources on weanling pig performance. J Anim Sci. 1998;76:3034-42.

33. Brewer MS, Zhu LG, McKeith FK. Marbling effects on quality characteristics of pork loin chops: consumer purchase intent, visual and sensory characteristics. Meat Sci. 2001;59:153-63.

34. Font-i-Furnols M, Tous N, Esteve-Garcia E, Gispert M. Do all the consumers accept marbling in the same way? The relationship between eating and visual acceptability of pork with different intramuscular fat content. Meat Sci. 2012;91:448-53.

35. Sasaki K, Motoyama M, Narita T. Increased intramuscular fat improves both 'chewiness' and 'hardness' as defined in ISO5492: 1992 of beef Longissimus muscle of Holstein $\times$ Japanese Black F1 steers. Anim Sci J. 2012;83:338-43.

36. Suárez-Belloch J, Latorre MA, Guada JA. The effect of protein restriction during the growing period on carcass, meat and fat quality of heavy barrows and gilts. Meat Sci. 2016;112:16-23.

37. Real DE, Nelssen JL, Unruh JA, Tokach MD, Goodband RD, Dritz SS, et al. Effects of increasing dietary niacin on growth performance and meat quality in finishing pigs reared in two different environments.J Anim Sci. 2002;80:3203-10.

38. Cameron ND, Penman JC, Fisken AC, Nute GR, Perry AM, Wood JD. Genotype with nutrition interactions for carcass composition and meat quality in pig genotypes selected for components of efficient lean growth rate. Anim Sci.1999;69:69-80.

39. Apple JK, Maxwell CV, Brown DC, Friesen KG, Musser RE, Johnson ZB, et al. Effects of dietary lysine and energy density on performance and carcass characteristics of finishing pigs fed ractopamine.J Anim Sci. 2004;82:3277-87. 